\title{
DETERMINAN KETERLIBATAN LANSIA DALAM PASAR KERJA DI KABUPATEN SRAGEN
}

\begin{tabular}{|c|}
\hline $\begin{array}{c}\text { Jihad Lukis Panjawa }{ }^{\mathbf{1}} \text {, Joko Triyanto } \\
{ }^{\mathbf{2}} \\
{ }^{1} \text { Fakultas Ekonomi, Universitas Tidar; }{ }^{2} \text { Fungsional Statistisi Muda } \\
\text { Badan Pusat Statistik Kabupaten Sragen } \\
{ }^{1} \text { jipanjawa@untidar.ac.id; }{ }^{2} \text { joko.triyanto@bps.go.id }\end{array}$ \\
\hline
\end{tabular}

Diterima: Februari 2020; Direvisi: Februari 2020; Disetujui: April 2020

\begin{abstract}
The consequences of the increasing population become a dilemma in relation to the potential or challenge for national and regional development, such as increased life expectancy, increasing the number of elderly and dependency ratio. This research is objected to analyze the determinants of the elderly involvement in the job market. Case studies are conducted in Sragen Regency. Analysis tool used to answer research objectives using logit regression. It is a statistical analysis tool designed to measure the direction and magnitude of one or more variables to one or more dependent variables where the dependent variable is represented by a dummy variable. Dummy on the dependent variable is indicated by 1 as the elderly worker and 0 as other (leisure). The results showed that gender, head of the household relationship, marital status, education level and domicile had a significant effect on the decision of the elderly population to keep working or leisure time. Moreover, guarantees as measured by ownership of pension guarantees has no significant effect on the elderly's decision to work or leisure time.
\end{abstract}

\section{Keywords: labour market, elderly, characteristics.}

Abstraksi. Konsekuensi yang muncul akan peningkatan penduduk menjadi dilema, terkait potensi atau tantangan bagi pembangunan secara nasional maupun regional, seperti kondisi harapan hidup yang meningkat membuat peningkatan jumlah penduduk lansia dan rasio ketergantungannya. Tujuan dalam penelitian ini untuk menganalisis determinan keterlibatan lansia dalam pasar kerja. Studi kasus dilakukan di Kabupaten Sragen. Alat analisis yang digunakan adalah regresi logit. Regresi logit adalah suatu alat analisis statistik yang didesain untuk mengukur arah dan besarnya pengaruh satu atau lebih variabel terhadap satu atau lebih variabel dependen yang mana variabel dependen ditunjukkan dengan variabel dummy. Dummy pada variabel dependen ditunjukkan dengan 1 sebagai lansia bekerja dan 0 sebagai lainnya (leisure). Hasil penelitian menunjukkan bahwa jenis kelamin, hubungan kepala rumah tangga, status perkawinan, tingkat pendidikan dan domisili berpengaruh nyata terhadap keputusan penduduk lansia untuk tetap bekerja atau leisure time. Temuan lainnya adalah jaminan yang diukur dengan kepemilikan jaminan pensiun tidak menunjukkan perbedaan yang signifikan.

Kata kunci: pasar kerja, tenaga kerja lansia, karakteristik.

\section{PENDAHULUAN}

Kesejahteraan masyarakat yang hendak dicapai dalam pembangunan, perlu suatu proses atau upaya yang mampu mengembangkkan kegiatan ekonomi dan peningkatan taraf hidup masyarakaat.
Dalam konsep pembangunan ekonomi, pencapaian tingkat kesejahteraan masyarakat melibatkan banyak faktor atau multidimensional (Arsyad, 2010; Todaro \& Smith, 2011). Orientasi pembangunan dalam peningkatan kesejahteraan tidak 
hanya semata-mata diukur dengan peningkatan pendapatan. Ukuran lainnya yang tidak dapat diabaikan begitu saja adalah peningkatan kualitas sumber daya manusia. Salah satu dampak dari keberhasilan pembangunan nasional terutama dibidang kesehatan dan kesejahteraan nasional antara lain meningkatkan rata-rata usia harapan hidup (Pourmohammadi, Valibeigi, \& Sadrmousavi, 2014; Setiawan \& Hakim, 2013).

Umur harapan hidup saat lahir yang meningkat mencerminkan derajat kesehatan masyarakat yang semakin baik dalam semua aspek kesehatan disuatu wilayah (Badan Pusat Statistik, 2017). Di sisi lain, Rooij dalam International Labour Organization/ILO (2010) mengungkapkan bahwa peningkatan harapan hidup yang mencerminkan masa hidup penduduk memberikan konsekuensi logis dalam pembangunan, salah satunya tantangan sosial dari peningkatan lansia. Oleh karena itu, perlu adanya kebijakan akan kepastian terkait tingkat pendapatan yang memadai bagi lansia agar tidak membebani kapasitas generasi lebih muda (dependency ratio yang kecil) dan perlu mempertimbangkan masa kerja serta meningkatkan kemampuan pekerja lansia.

Peningkatan usia harapan hidup akan menyebabkan dinamika kependudukan yang meliputi struktur umur dan persebaran penduduk. Beberapa dekade terakhir, dinamika kependudukan terjadi di Sragen, Jawa Tengah dan Indonesia. Berdasarkan data Badan Pusat Statistik (2019) menunjukkan tren usia harapan hidup mengalami peningkatan dari tahun ke tahun. Pada tahun 2010, usia harapan hidup di Indonesia sebesar 69,81 dan meningkatan menjadi 71,20 di tahun 2018 . Tren positif usia harapan hidup juga terjadi di Jawa Tengah. Usia harapan hidup di Jawa Tengah pada tahun 2018 sebesar 74,18, meningkat cukup signifikan dibandingkan tahun 2010 sebesar 72,73, sedangkan di Sragen, tahun 2018 usia harapan hidup sebesar 75,60, angkat tersebut meningkat dari tahun 2010 yang sebesar 75,05. Hal ini menunjukkan bahwa usia harapan hidup di Kabupaten Sragen lebih tinggi dibandingkan Provinsi Jawa Tengah maupun Nasional.

Kabupaten Sragen memiliki rasio ketergantungan lansia lebih tinggi dari Jawa Tengah dan Nasional. Rasio ketergantungan Kabupaten Sragen pada tahun 2018 sebesar 16,06, jika dibandingkan dengan Jawa Tengah dan Nasional hanya sebesar 13,03 dan 14,49 (Badan Pusat Statistik, 2019b; Badan Pusat Statistik Jawa Tengah, 2018). Peningkatan rasio ketergantuan menunjukkan penduduk usia lansia bertambah sebagai konsekuensi logis dari dampak meningkatnya usia harapan hidup dan dominasi penduduk usia muda yang produktif (Heryanah, 2015; Junaidi \& Hardiani, 2009). Peningkatan usia harapan hidup dan dominasi penduduk usia muda yang produktif kelak akan meningkatkan penduduk lansia. Menurut Badan Pusat Statistik (2018b) baby boom yang terjadi beberapa dekade lalu, menciptakan tantangan tersendiri dan mengubah tatanan demografi. Sisi positif yang dapat dipahami adalah peningkatan lansia menunjukkan keberhasilan program-program pemerintah terkait layanan kesehatan beserta turunannya dalam pembangunan. Namun, di sisi lain, meningkatnya jumlah lansia membawa kosekuensi ketika persiapan pralansia (saat didominasi penduduk usia produktif) untuk menyambut jumlah lansia tidak diantisipasi dengan baik yang menyebabkan lansia di masa datang jauh dari sejahtera 
Peningkatan usia harapan hidup akan menimbulkan terjadinya transisi demografi. Skema transisi tersebut dapat terjadi transisi dari tingkat pertumbuhan pada level dan kelahiran tinggi menuju tingkat pertumbuhan yang rendah pada level kelahiran dan kematian yang rendah. Tingkat kematian yang menurun lebih cepat sebagai dampak dari perbaikan gizi, ilmu pengetahuan dan teknologi di bidang kesehatan. Selain itu tingkat kelahiran secara berangsur - angsur mengalami penurunan sebagai dampak dari pembangunan yang menyebabkan perubahan struktural dan perubahan sosial. Bentuk perubahan struktural dapat berupa industrialisasi dan urbanisasi, sedangkan perubahan sosial dapat mencakup tingkat pendidikan dan tingkat kesehatan yang meningkat, serta tingkat kelahiran yang menurun. Oleh karena itu dengan adanya perubahan struktural dan perubahan sosial berdampak pada naiknya usia harapan hidup sehingga prosentase penduduk lansia semakin tinggi.

Implikasi yang penting dari peningkatan jumlah lansia adalah peningkatan rasio ketergantungan usia lanjut. Setiap penduduk usia produktif harus menanggung semakin banyak lansia. Jumlah lansia yang meningkat memunculkan permasalahan dalam pasar tenaga kerja, di mana saat lansia tidak ingin membebani penduduk usia produktif dan tetap memilih untuk bertahan di pasar tenaga kerja yang mengakibatkan persaingan dalam penyerapan tenaga kerja. Selain itu permasalahan ekonomi yang dialami lansia yaitu tentang pemenuhan kebutuhan hidup sehari - hari seperti sandang, pangan, perumahan kesehatan, rekreasi dan sosial.

Seorang individu masuk di pasar tenaga kerja dikarenakan kondisi trade off untuk mencapai kesejahteraan dengan cara menggunakan waktunya untuk bekerja. Individu mendapatkan uang untuk membeli kebutuhan sehari-hari. Individu memilih untuk bekerja akan mengorbankan beberapa waktu luangnya. Dengan kata lain, memilih untuk tetap bekerja atau individu tersebut tidak dapat menikmati waktu luang yang lebih besar dibandingkan saat individu lebih memilih untuk tidak bekerja guna menikamati waktu luang yang lebih banyak. Berdasarkan hal tersebut, penawaran tenaga kerja merupakan hasil keputusan untuk bekerja atau menikmati waktu luang. Perilaku penawaran tenaga kerja lansia dalam penelitian ini didasarkan pada model neoklasik dari pilihan bekerja atau waktu luang (Neoclassical Modal of Labor or Leisure Choice).

Menurut Borjas (2016), Neoclassical Modal of Labor or Leisure Choice adalah preferensi tenaga kerja pada model neoklasik mengenai pilihan individu untuk bekerja atau menikmati waktu luang yang dapat ditunjukkan dengan kepuasan individu baik dari konsumsi barang dan menikmati waktu luang. Lebih jelasnya, individu akan mengkonsumsi banyak jenis barang yang berbeda pada periode tertentu. Konsumsi barang sebagai nilai keseluruhan uang dari semua barang yang dibeli oleh individu pada periode tertentu dan waktu yang sama pada saat menikmati waktu luang menyatakan jumlah jam dari waktu luang yang dinikmati oleh individu. Kombinasi dari konsumsi barang dan menikmati waktu luang oleh individu pada tingkat kepuasan yang sama dapat ditunjukkan dengan fungsi utilitas (kepuasan). Fungsi utilitas mentransfomasi konsumsi barang dan menikmati waktu luang individu menjadi indeks utilitas yang mengukur tingkat kepuasan individu. Semakin tinggi indeks utilitas, kebahagian individu semakin meningkat. Asumsi yang 
dapat dibangun adalah membeli lebih banyak barang atau memiliki waktu luang lebih banyak untuk meningkatkan kepuasan individu tersebut. Konsumsi barang dan menikmati waktu luang individu terkendala oleh waktu dan pendapatan atau yang sering disebut budget constraint. Perlu diketahui bahwa dalam menikmati waktu luang, individu akan tetap mengkonsumsi dengan pendapatan yang diperoleh diluar jam kerja atau terlepas dari berapa jam individu bekerja atau disebut pendapatan bukan tenaga kerja, jumlah jam kerja dialokasikan oleh individu di pasar tenaga kerja pada periode tertentu dan tingkat upah perjam. Pendapatan bagian dari individu tersebut misalnya bersumber dari pendapatan properti, deviden, dan hadiah undian.

Tingkat upah memberikan peranan dalam keputusan penawaran tenaga kerja setiap individu. Asumsi awal bahwa tingkat upah konstan untuk individu tertentu, jadi individu tersebut menerima upah perjam yang sama tanpa menghiraukan berapa banyak jam individu bekerja. Pada kenyataanya, tingkat upah "marginal" (yaitu tingkat upah yang diterima untuk jam terakhir bekerja) umumnya tergantung pada berapa banyak jam individu bekerja. Individu yang bekerja dalam 40 jam atau lebih per minggu, biasanya menerima sebuah premi lembur, dan tingkat upah pada pekerjaan paruh waktu seringkali lebih rendah daripada tingkat upah pada pekerjaan full-time. Dengan mengabaikan kemungkinan bahwa upah marjinal seorang pekerja mungkin tergantung kepada berapa banyak jam individu memilih untuk bekerja. Berdasarkan asumsi tersebut individu akan memilih kombinasi antara mengkonsumsi barang dan menikmati waktu luang yang menghasilkan kepuasan pada tingkat indeks kepuasan tertinggi yang dibatasi oleh budget constraint (Borjas, 2016).

Menurut teori ekonomi neoklasik penawaran tenaga kerja akan bertambah bila tingkat upah bertambah. Penawaran tenaga kerja dapat menimbulkan kendala berupa pendapatan yang akan diperoleh pada saat waktu luang. Pendapatan yang diperoleh dapat digunakan untuk membeli barang dan jasa, termasuk juga memanfaatkan waktu yang dimiliki untuk bersenang - senang. Berdasarkan hal tersebut, di negara berkembang seperti Indonesia para lansia yang tidak bisa menikmati waktu luang ini menjadi amat menyedihkan mengingat saat keinginan waktu luang ini muncul maka akan tertutup oleh tingginya kebutuhan hidup yang harus dipenuhi.

Latar belakang dari beberapa kajian penelitian sebelumnya tentang keputusan lansia masuk di pasar tenaga kerja untuk tetap bekerja atau menikmati waktu luang adalah faktor sosial, ekonomi, demogarafi, dan geografi (Affandi, 2009; Andini, Nilakusmawati, Putu, \& Susilawati, 2007; Borjas, 2016; Hotopp, 2005; Kalwij \& Vermeulen, 2005; Reddy, 2016; Ruhm, 1996; Williamson \& Mcnamara, 2001). Dari aspek sosial dan demografi (Affandi, 2009; Andini et al., 2007; Giang \& Pfau, 2010; Hotopp, 2005; Kalwij \& Vermeulen, 2005; Ruhm, 1996; Utami \& Rustariyuni, 2016), aspek ekonomi (Boskin, 1975; Crawford \& Lilien, 1981; Quinn, 2014; Reddy, 2016), aspek geografi (Lee, 2009; Reddy, 2016).

Lansia dengan kondisi sosial dan ekonomi yang paling kurang beruntung memiliki tingkat partisipasi angkatan kerja tertinggi. Hal tersebut menunjukkan kurang relatifnya jaminan sosial dihari tua. Lansia berpendidikan dan pendapatan rendah, serta memiliki jaminan kesehatan yang buruk 
memberikan peluang besar untuk tetap bekerja di masa tuanya. Lebih lanjut, lansia dalam kondisi miskin akan lebih mungkin untuk berpartisipasi dalam angkatan kerja, terutama di sektor informal dengan bayaran rendah (Affandi, 2009; Reddy, 2016; Williamson \& Mcnamara, 2001). Kajian dari aspek demografi, laki-laki lansia dengan berstatus kawin dan sebagai kepala rumah tangga berpeluang lebih besar untuk bekerja dibandingkan perempuan lansia. (Affandi, 2009; Giang \& Pfau, 2010; Utami \& Rustariyuni, 2016). Berdasarkan kondisi wilayah, menurut Lee (2009) dan Reddy (2016) partisipasi lansia bekerja di pedesaan masih tinggi disebabkan oleh kondisi wilayah yang masih buruk. Mayoritas pekerja lansia menghadapi kondisi kerja yang buruk dan upah yang rendah di sektor informal. Junaidi, Erfit, dan Prihanto (2017) menambahkan bahwa tingkat kesejahteraan lansia dan keluarganya yang lebih rendah di perdesaan dibandingkan perkotaan menyebabkan lansia terpaksa harus tetap bekerja untuk mencukupi kebutuhan hidup keluarga. Selain itu, relatif lebih banyaknya kesempatan kerja yang lebih mudah dimasuki oleh lansia di perdesaan karena tidak membutuhkan persyaratan pendidikan/keterampilan tertentu di perdesaan dibandingkan kesempatan kerja di perkotaan.

Berdasarkan uraian di muka, penelitian ini bertujuan untuk menganalisis faktorfaktor keterlibatan lansia dalam pasar kerja bekerja di Kabupaten Sragen.

\section{METODE PENELITIAN}

Jenis data yang digunakan dalam penelitian ini adalah data sekunder yang bersumber dari SAKERNAS Agustus 2019, Badan Pusat Statistik Kabupaten Sragen. Metode analisis yang digunakan untuk menjawab tujuan dalam penelitian ini adalah regresi logit. Menurut Gujarati dan Porter (2009), regresi logit adalah suatu alat analisis statistik yang didesain untuk mengukur arah dan besarnya pengaruh satu atau lebih variabel terhadap satu atau lebih variabel dependen yang mana variabel dependen ditunjukkan dengan variabel dummy. Variabel dependen (P dalam persamaan 1) untuk 1 menunjukkan partisapasi lansia bekerja pada periode tertentu dan bernilai 0 untuk lainnya (leisure). Secara umum model logit dikotomi dinotasikan sebagai berikut:

$\ln \left(\frac{P\left(Y=1 \mid X_{i}\right)}{P\left(Y=0 \mid X_{i}\right)}\right)=\ln \left(\frac{P_{i}}{1-P_{i}}\right)=$

$Z_{i}=\beta_{0}+\beta_{1} X_{1}+\cdots+\beta_{i} X_{i}$

Dengan,

$P_{i}=\frac{1}{1+e^{-\left(\beta_{0}+\beta_{1} X_{1}+\cdots+\beta_{i} X_{i}\right)}}=\frac{1}{1+e^{-z_{i}}}$

$=\frac{e^{Z_{\hat{i}}}}{1+e^{Z_{i}}}$

$1-P_{i}=\frac{1}{1+e^{z_{i}}}$

$\frac{P_{i}}{\left(1-P_{i}\right)}$ adalah Odd Ratio atau rasio peluang suatu kejadian. Berdasarkan persamaan (1), model regresi logit penduduk lansia dinyatakan sebagai berikut:

$\ln \left(\frac{P_{i}}{1-P_{i}}\right)=\beta_{0}+\beta_{1}$ jen_kel $+\beta_{2}$ hub_krt + $\beta_{3}$ stat_kaw $+\beta_{4}$ pend $+\beta_{5}$ jam_pens $+\beta_{6}$ dom

Dengan,

P : partisipasi kerja penduduk lansia (bekerja $=1$, tidak bekerja $=0$ )

jen_kel $:$ jenis kelamin (laki-laki $=1$, perempuan $=0$ )

hub_krt : hubungan kepala rumah tangga (kepala rumah tangga $=1$, lainnya $=0$ ) 
stat_kaw : status perkawinan (belum kawin $=1$, lainnya $=0$ )

pend : tingkat pendidikan (pendidikan dibawah atau sama dengan SMA $/$ sederajat $=1$ dan Diploma/Sarjana $=0$ )

jam_pens : jaminan pensiun (tidak memiliki jaminan pensiun $=1$, memiliki $=0$ )

dom : domisili (perdesaan $=1$, perkotaan $=0$ )

$\beta_{\mathrm{i}} \quad$ : koefisien regresi

$\mathrm{e}_{\mathrm{i}} \quad$ : error term.

Pada model logit, karakteristik demografi, sosial, ekonomi yang digunakan antara lain jenis kelamin, hubungan dengan kepala rumah tangga, status perkawinan, tingkat pendidikan dan jaminan pensiun. Pada aspek geografis dalam penelitian ini adalah lansia yang tinggal di perkotaan dan perdesaan.

\section{HASIL DAN PEMBAHASAN}

Jumlah lansia meningkat merupakan konsekuensi logis keberhasilan pembangunan di bidang kesehatan karena peningkatan usia harap hidup saat lahir. Jumlah lansia yang meningkat menjadi permasalahan dalam pasar tenaga kerja. Permasalahan yang terjadi adalah ketika lansia tidak ingin membebani penduduk usia produktif dan tetap memilih untuk bertahan di pasar tenaga kerja yang mengakibatkan persaingan dalam penyerapan tenaga kerja. Lebih lanjut, regres logit digunakan untuk menganalisis faktor-faktor yang mempengaruhi keterlibatan lansia dalam pasar kerja di Kabupaten Sragen.

Model regresi logit keputusan lansia bekerja atau leisure time di Kabupaten Sragen tahun 2019 dalam bentuk transformasi logit adalah:

$$
\begin{aligned}
\ln \left(\frac{P_{i}}{1-P_{i}}\right)= & -20,274+0,890 \text { jen_kel }+0,339 \\
& \text { hub_krt }-0,305 \text { stat_kaw }-\beta_{4} \\
& 0,256+20,449 \text { jam_pens - } \\
& 0,368 \text { dom }
\end{aligned}
$$

Uji hipotesis menggunakan uji Wald sebagaimana disajikan dalam Tabel 1 menunjukkan bahwa koefisien regresi logistik signifikan secara statistik pada tingkat kesalahan 1 persen.

Tabel 1.

Hasil Estimasi Regres Logit Keputusan Lansia Bekerja dan Leisure

\begin{tabular}{lrrrr}
\hline \multicolumn{1}{c}{ Variabel } & \multicolumn{1}{c}{ B } & \multicolumn{1}{c}{ Wald } & \multicolumn{1}{c}{ Sig. } & $\operatorname{Exp}(\mathrm{B})$ \\
\hline jen_kel & 0,890 & 4102,046 & $0,000^{*}$ & 2,434 \\
hub_krt & 0,339 & 558,760 & $0,000^{*}$ & 1,403 \\
stat_kaw & $-0,305$ & 15,764 & $0,000^{*}$ & 0,737 \\
pend & $-0,256$ & 418,333 & $0,000^{*}$ & 0,774 \\
jam_pens & 20,449 & 0,000 & 0,993 & 759939130,393 \\
dom & $-0,368$ & 1019,768 & $0,000^{*}$ & 0,692 \\
Constant & $-20,274$ & 0,000 & 0,993 & 0,000 \\
\hline
\end{tabular}

Keterangan: " $\mathrm{p}<0,01$ (1 persen); $\mathrm{B}$ adalah koefisien; sig adalah $p$ value; $\operatorname{Exp}(\mathrm{B})$ adalah eksponen dari nilai $\mathrm{B}$.

Jenis kelamin penduduk usia lanjut akan mempengaruhi peranan, pembagian tugas dan aktivitas yang dilakukan baik dalam keluarga maupun dalam masyarakat.
Aktivitas lansia laki-laki berbeda dengan aktivitas lansia perempuan. Koefisien variabel jenis kelamin (jen_kel) bertanda positif menunjukkan bahwa lansia laki-laki 
cenderung lebih besar untuk bekerja dibanding lansia perempuan. Nilai odd Ratio sebesar 2,434 menunjukkan bahwa besarnya kecenderungan lansia laki-laki untuk bekerja adalah 2,434 kali dibanding lansia perempuan. Hal ini menunjukkan bahwa laki-laki, walaupun usianya telah lanjut, masih tetap sebagai pencari nafkah utama. Umumnya tanggung jawab untuk memenuhi perekonomian keluarga berada di pundak laki-laki dibandingkan perempuan. Hasil penelitian ini sejalan dengan Affandi (2009) serta Giang dan Pfau (2010).

Nilai variabel hubungan kepala rumah tangga (hub_krt) sebesar 0,339 artinya lansia sebagai kepala rumah tangga cenderung lebih besar untuk bekerja dibanding lainnya (pasangan kepala rumah tangga, anak, menantu, cucu, famili lainnya). Nilai Odd Ratio 1,403 menunjukkan bahwa kecenderungan lansia sebagai kepala rumah tangga untuk bekerja sebasar 1,403 kali dibanding lainnya. Status hubungan kepala rumah tangga akan mempengaruhi seseorang penduduk usia lanjut untuk bekerja. Seorang penduduk usia lanjut yang berstatus sebagai kepala rumah tangga tentu dituntut tanggung jawabnya terhadap kelangsungan hidup anggota rumah tangganya. Agar dapat memenuhi kebutuhan hidupnya maupun anggota rumah tangganya, lansia harus mempunyai penghasilan yang diperoleh dengan cara bekerja. Hasil penelitian ini sejalan dengan Giang dan Pfau (2010) serta Utami dan Rustariyuni (2016).

Variabel status perkawinan (stat_kaw) lansia dalam penelitian ini dikategorikan menjadi dua yaitu belum kawin dan lainnya, Kategori lainnya disini mencakup status perkawinan kawin, cerai hidup dan cerai mati. Dari Tabel 1 terlihat bahwa koefisien variabel stat_kaw bertanda negatif yang berarti lansia yang belum kawin cenderung lebih kecil untuk bekerja dibanding yang berstatus perkawinan lainnya. Nilai Odd Ratio sebesar 0,737 menunjukkan bahwa kecenderungan lansia yang belum kawin untuk bekerja lebih kecil 0,737 kali dibandingkan dengan lansia dengan status perkawinan lainnya. Berdasarkan hasil tersebut, dapat dikatakan bahwa penduduk lansia yang tidak kawin ataupun sudah cerai mempunyai kecenderungan untuk bekerja lebih kecil bila dibandingkan penduduk lansia yang berstatus kawin. Kemungkinan kondisi ini terjadi karena lansia tersebut sudah tidak punya pasangan hidup sehingga tinggal dengan rumah tangga anaknya yang mampu menghidupinya atau meskipun tidak tinggal dengan anaknya mereka mungkin sudah mendapat jaminan atau kiriman dari anakanaknya. Hasil penelitian ini berbeda dengan yang dilakukan oleh Affandi (2009).

Variabel tingkat pendidikan (pend) dikategorikan menjadi dua yaitu lansia yang berpendidikan kurang atau sama dengan SMA dan lainnya. Kategori lainnya mencakup berpendidikan tinggi baik diploma maupun sarjana. Variabel tingkat pendidikan memiliki koefisien bertanda negatif, hal ini mengandung makna bahwa penduduk lansia yang berpendidikan kurang dari atau sama dengan SMA cenderung lebih kecil untuk bekerja dibanding mereka para lansia yang berpendidikan tinggi. Nilai Odd Ratio variabel tingkat pendidikan sebesar 0,774 menyatakan bahwa lansia yang berpendidikan kurang dari atau sama dengan SMA memiliki kecenderungan untuk bekerja lebih kecil 0,774 kali dibandingkan lansia yang berpendidikan tinggi. Bagi mereka yang berpendidikan tinggi dan pada saat lansia masih bekerja, 
umumnya mereka merupakan lansia yang masih dibutuhkan sumbangan pemikirannya. Hasil penelitian ini berbeda dengan yang dilakukan oleh Affandi (2009).

Secara normatif penduduk lanjut usia akan bekerja jika tidak ada sumber pendapatan yang diperoleh selain dengan bekerja. Jika mereka memiliki jaminan hari tua, pensiun, maupun jaminan sosial lainnya dan itu mencukupi tentu memilih untuk tidak bekerja. Bagi yang memiliki jaminan tetapi bekerja alasannya biasanya hanya untuk aktualisasi diri dan supaya "bergerak" melalui aktivitas bekerja karena bergerak menyehatkan. Namun, berdasarkan Tabel 1 dapat diketahui bahwa jaminan pensiunan tidak berpengaruh dalam keputusan lansia bekerja atau leisure. Hal ini berarti baik yang memiliki jaminan sosial maupun yang tidak tetap aktif di pasar kerja untuk memperoleh pendapatan. Kecenderungan lansia bekerja di sektor informal dibandingkan sektor formal tidak berpengaruh nyata terhadap keputusan lansia dalam memilih bekerja atau menikmati waktu luang.

Variabel domisili (dom) memiliki koefisien -0,368 menyiratkan lansia yang berdomisili di perdesaan lebih kecil untuk bekerja dibanding yang tinggal di perkotaan. Nilai Odd Ratio sebesar 0,692 berarti kecenderungan lansia yang berdomisili di kota untuk bekerja 0,692 kali dibanding di desa. Lebih besarnya probabilitas bekerjanya lansia di perkotaan diduga disebabkan oleh dua hal. Pertama, tingkat kesejahteraan lansia dan keluarganya yang lebih rendah di perdesaan berusaha berpindah ke perkotaan untuk mencari pekerjaan yang lebih baik, karena lansia "terpaksa" harus tetap bekerja untuk mencukupi kebutuhan hidup keluarga. Kedua, relatif lebih banyaknya kesempatan kerja yang lebih mudah dimasuki oleh lansia di perkotaan. Hasil penelitian ini sama dengan yang dilakukan oleh Lee (2009) dan Reddy (2016).

\section{SIMPULAN}

Dari hasil analisis menggunakan regres logit diketahui bahwa faktor jenis kelamin, hubungan kepala rumah tangga, status perkawinan, tingkat pendidikan dan domisili berpengaruh nyata terhadap keputusan lansia untuk bekerja atau menikmati waktu luang (leisure time), tetapi faktor jaminan pensiun tidak berpengaruh signifikan.

Ditinjau dari nilai Odd Ratio-nya dapat disimpulkan bahwa lansia laki-laki untuk bekerja adalah 2,434 kali dibanding lansia perempuan, lansia sebagai kepala rumah tangga untuk bekerja sebesar 1,403 kali dibanding lainnya, lansia yang belum kawin untuk bekerja lebih kecil 0,737 kali dibandingkan dengan lansia dengan status perkawinan lainnya, lansia yang berpendidikan kurang dari atau sama dengan SMA memiliki kecenderungan untuk bekerja lebih kecil 0,774 kali dibandingkan lansia yang berpendidikan tinggi dan lansia yang berdomisili di kota untuk bekerja 0,692 kali dibanding di desa.

Secara umum, tampaknya kondisi penduduk lansia harus lebih diperbaiki. Pemerintah perlu membuat kebijakankebijakan untuk melindungi para lansia di masa tuanya. Cakupan skema pensiun maupun tunjangan dan asuransi kesehatan perlu diperluas agar lansia terproteksi kehidupannya dan kesejahteraannya. Pemerintah perlu mulai merumuskan kebijakan pensiun bagi lansia yang tidak bekerja disektor formal. Selain itu pemberdayaan lansia yang juga dirasa perlu guna meningkatkan kesejahteraannya. Perlu adanya keterlibatan peran pemerintah, 
swasta dan masyarakat secara bersamasama guna meningkatkan kesejahteraan masyarakat yang diharapkan mampu menyasar seluruh golongan maupun elemen masyarakat dalam mengelola sumber daya yang ada dan membentuk suatu pola kemitraan.

\section{DAFTAR PUSTAKA}

Affandi, M. (2009). Faktor-Faktor yang Mempengaruhi Penduduk Lanjut Usia Memilih untuk Bekerja. Journal of Indonesian Applied Economics, 3(2), 99-110.

Andini, N. K., Nilakusmawati, Putu, D. E., \& Susilawati, M. (2007). Faktor-Faktor yang Mempengaruhi Penduduk Lanjut Usia Masih Bekerja. Jurnal Kependudukan Dan Pengembangan Sumber Daya Manusia, 9(1), 44-49.

Arsyad, L. (2010). Ekonomi Pembangunan. Yogyakarta: STIM YKPN.

Badan Pusat Statistik. (2017). Indeks Pembangunan Manusia 2017. Jakarta: Badan Pusat Statistik.

Badan Pusat Statistik. (2018). Statistik Penduduk Lanjut Usia. Jakarta: Badan Pusat Statistik.

Badan Pusat Statistik. (2019a). Indeks Pembangunan Manusia. Jakarta: Badan Pusat Statistik.

Badan Pusat Statistik. (2019b). Statistik Penduduk Lanjut Usia. Jawa Tengah: Badan Pusat Statistik.

Badan Pusat Statistik Jawa Tengah. (2018). Profil Lansia Provinsi Jawa Tengah. Semarang: Badan Pusat Statistik Jawa Tengah.

Borjas, G. (2016). Labor Economics (4th ed.). New York: McGraw-Hill.

Boskin, M. J. (1975). Social Security and Retirement Decisions (No. 107).

Crawford, V. P., \& Lilien, D. M. (1981). Social Security and the Retirement Decision. The Quarterly Journal of Economics, 96(3), 505-529.

Giang, L. T., \& Pfau, W. D. (2010). A Gender Perspective on Elderly Work in Vietnam (No. 24946).

Gujarati, D. N., \& Porter, D. C. (2009). Basic of Econometric (5th ed.). New York: McGraw-Hill Education.

Heryanah. (2015). Ageing Population Dan Bonus Demografi Kedua Di Indonesia. Populasi, 23(2), 1-16.

Hotopp, U. (2005). The employment rate of older workers. In Labour Market Trends, February 2005.

International Labor Organization. (2010). ILO, Universitas Indonesia tangani masalah pekerja lansia dan produktivitas di Indonesia. Retrieved February 10, 2019, from International Labor Organization website: http://www.ilo.org/jakarta/info/public/pr/WCMS_124485/lang--en/index.htm

Junaidi, Erfit, \& Prihanto, P. H. (2017). Faktor-faktor sosial ekonomi yang mempengaruhi keterlibatan penduduk lanjut usia dalam pasar kerja di Provinsi Jambi. Masyarakat, Kebudayaan Dan Politik, 30(2), 197-205. 
Junaidi, \& Hardiani. (2009). Dasar-dasar Teori Kependudukan. Jambi: Hamada Prima.

Kalwij, A., \& Vermeulen, F. (2005). Labour Force Participation of the Elderly in Europe: The Importance of Being Healthy (No. 1887).

Lee, C. (2009). Labor Force Participation of Older Males in Korea: 1955-2005 (No. 14800).

Neuman, W. L. (2011). Sosial Research Methods: Quantitative and Qualitative Approaches. Boston: Pearson Education, Inc.

Pourmohammadi, M. R., Valibeigi, M., \& Sadrmousavi, M. S. (2014). The Quality of Life and Regional Convergence in Iranian Provinces. Regional Science Inquiry, 6(1), 111126.

Quinn, J. F. (2014). Microeconomic Determinants of Early Retirement: A Cross-Sectional View of White Married Men. The Journal of Human Resources, 12(3), 329-346.

Reddy, A. B. (2016). Labour Force Participation of Elderly in India: Patterns and Determinants. International Journal of Social Economics, 43(5), 1-24.

Ruhm, C. J. (1996). Gender Differences in Employment Behavior During Late Middle Age. Journals of Gerontology; Series B: Psychological Sciences \& Social Sciences, $51 B(1), \mathrm{S} 11-\mathrm{S} 17$.

Setiawan, M. B., \& Hakim, A. (2013). Indeks Pembangunan Manusia Indonesia. Jurnal Economia, 9(1), 18-26.

Todaro, P. M., \& Smith, S. C. (2011). Pembangunan Ekonomi. Jakarta: Erlangga.

Utami, N. P. D., \& Rustariyuni, S. D. (2016). Pengaruh Variabel Sosial Demografi terhadap Keputusan Penduduk Lanjut Usia Memilih Bekerja di Kecamatan Kediri. Jurnal Ekonomi Kuantitatif Terapan, 9(2), 135-141.

Williamson, J. B., \& Mcnamara, T. K. (2001). Why Some Workers Remain In The Labor Force Beyond The Typical Age Of Retirement. In Center for Retirement Research at Boston College. 